\title{
Insecticidal efficacy and chemical composition of Balanites aegyptiaca (L.) Delile seed oils against Tribolium castaneum Herbst (Coleoptera: Tenebrionidae)
}

\author{
Mokhtar Mohamedalamin Mokhtar ${ }^{1}$, Jianfeng $\mathrm{Li}^{1}$, Zhiping Du ${ }^{1}$, and Fangqin Cheng ${ }^{{ }^{*}}$ \\ ${ }^{1}$ Shanxi University, Institute of Resources and Environmental Engineering, Nº 92 Wucheng Road, Taiyuan 030006, Shanxi, China. \\ *Corresponding author (cfangqin@sxu.edu.cn).
}

Received: 14 July 2020; Accepted: 3 October 2020; doi:10.4067/S0718-58392021000100102

\begin{abstract}
Botanical pesticides are a new trend for pest management because they are an environmentally safe alternative for synthetic chemicals. The aim of this study was to investigate the insecticidal activity of desert date (Balanites aegyptiaca [L.] Delile) seed oils against the red flour beetle (Tribolium castaneum Herbst) and determine the oil chemical compounds by gas chromatography-mass spectrometry. Oils were extracted by chloroform, hexane, and ethanol, and they were tested on the pest by the film residue method at doses of 1.131, 0.566, 0.283, and $0.142 \mathrm{mg} \mathrm{cm}^{-2}$ after 12, 24, 36, and $48 \mathrm{~h}$. Results showed that chloroform achieved a $100 \%$ mortality rate at 1.131 and $0.566 \mathrm{mg} \mathrm{cm}^{-2}$ after 12 and $36 \mathrm{~h}$ exposure, respectively. Meanwhile, the hexane extract caused a similar effect after 24 and $48 \mathrm{~h}$ at the same doses, respectively. The chloroform extract scored the lowest median lethal dose $\left(\mathrm{LD}_{50}, 0.134 \mathrm{mg} \mathrm{cm}^{-2}\right)$ against the pest after $48 \mathrm{~h}$ of exposure. This finding indicated that chloroform extract was the most toxic for T. castaneum compared with the other extracts. The results of the oil analysis revealed that (9Z,12Z)-octadeca-9,12-dienoic acid, hexadecanoic acid, $(Z)$-octadec-9-enoic acid, and (E)-octadec-6enoic acid were the main components, but the concentration differed from one extract to another. These results suggest that chloroform and hexane extracts have potent insecticidal activity and could be used in grain storage to control pests.
\end{abstract}

Key words: Chloroform extract, contact toxicity, desert date, $\mathrm{LD}_{50}$, Tribolium castaneum.

\section{INTRODUCTION}

Stored product pests can cause damage and economic loss for grains and commercial products. Insects damage the stored products by direct feeding or contaminating commodities with body parts and setae, and can render them unpalatable or unmarketable. Moreover, insect pest infestation reduces the rate of seed germination and viability and promotes infections involving bacterial and fungal diseases (Lazzari and Lazzari, 2012; Johnson, 2013; Yaseen et al., 2019). Therefore, many pesticides, particularly fumigation pesticides, have been used to control stored grain pests (Wijayaratne et al., 2018; Agrafioti et al., 2019). This approach has created many problems, the most important being toxicity to humans and animals, the increasing cost of pesticides, and emergence of insect strains resistant to most pesticides (Maksymiv, 2015; Damalas and Koutroubas, 2016).

The previously mentioned problems and many other known drawbacks of synthetic pesticides have created the urgent need to develop new alternatives of chemical control, provided that new measures are economically viable, environmentally safe, and ecologically compatible. Therefore, various alternative measures were studied to resolve pesticide problems, such as the evaluation of botanical extracts (Satti and Elamin, 2012; Dhaniya and Dayanandan, 2016; Chiffelle et al., 2019; Mendoza-García et al., 2019; Rahim and Iqbal, 2019). This method has several advantages; 
for example, easily applied, safe for humans and the environment, easily biodegradable plant extracts, acceptable price affordable by traditional farmers, selectivity, and high efficacy (Rozman, 2015; Trivedi et al., 2018). Several plants, such as the desert date, contain bioactive compounds that can be used to control pests.

The desert date (Balanites aegyptiaca [L.] Delile; Zygophyllaceae) is found in most arid to sub-humid areas of Africa and South Asia (Chothani and Vaghasiya, 2011). The tree is widely distributed in the drylands of Africa from Mauritania to Nigeria and eastward to Ethiopia, Somalia, and East Africa (Manji et al., 2013). It contains many secondary metabolites such as alkaloids, saponins, steroids, flavonoids, tannins, and phenolic compounds (Al-Thobaiti and Abu Zeid, 2018; Satpute and Vanmare, 2018; Hu et al., 2019). These multiple chemicals possess different biological activity such as mosquitocidal, larvicidal, and insecticidal properties (Djeghader et al., 2018; Jatau et al., 2018). Therefore, the aim of the study was to evaluate the insecticidal activity of $B$. aegyptiaca seed oils against Tribolium castaneum Herbst and determine the oil chemical compounds by gas chromatography-mass spectrometry (GC-MS).

\section{MATERIALS AND METHODS}

\section{Plant materials and insects}

Balanites aegyptiaca (L). Delile fruits were collected in September 2018 from the ground under naturally grown trees in the Alsondodab zone $\left(15^{\circ} 22^{\prime} 21^{\prime \prime}\right.$ N, 3243’22” E; 397 m a.s.1.), Khartoum state, Sudan. The collected fruits were identified by Professor Abdalla Abdelrahim Satti, Department of Alternatives to Pesticides and Biocontrol, Environment and Natural Resources Research Institute, National Center for Research, Khartoum, Sudan. Powders were prepared from seed kernels by crushing fruits with a mortar and pistil (locally made in Khartoum, Sudan) and pulverized in an electric blender (Panasonic, MX-J220P, Shanghai, China). These powders were kept in dark bottles to protect them from light degradation, and they were taken to the laboratory at the Institute of Resources and Environmental Engineering, Shanxi University, Shanxi, China. Meanwhile, temperature and relative humidity (RH) at the laboratory ranged from 20 to $25^{\circ} \mathrm{C}$ and $25 \%$ to $35 \%$, respectively.

Tribolium castaneum Herbst, already identified by the College of Life Sciences at the university, was obtained from a crop and kept at the laboratory of the Institute of Resources and Environmental Engineering, Shanxi University. The insects were reared in glass jars $\left(1200 \mathrm{~mL}\right.$ ) inside an incubator (Lichen, HSP-70BE, Shanghai, China) at $30 \pm 2{ }^{\circ} \mathrm{C}$ and $65 \pm 8 \%$ RH and fed wheat flour (Mishra et al., 2016). For the experiment, 1-7 d old adult insects of mixed sex were selected.

\section{Oil extraction and analysis}

The maceration method was used to extract the oils of B.aegyptiaca with the three extraction solvents hexane, chloroform, and ethanol. Seed powders $(50 \mathrm{~g})$ were placed in conical flasks $(500 \mathrm{~mL})$ and $200 \mathrm{~mL}$ of each solvent was added separately. The conical flasks were stirred with a magnetic mixer for $30 \mathrm{~min}$ and allowed to soak at room temperature for $7 \mathrm{~d}$ (Gupta et al., 2016). The filtrate was obtained with a vacuum filter pump with Whitman filter paper. The solvent was evaporated under reduced pressure at 15 to $35^{\circ} \mathrm{C}$ with a rotary evaporator (Yar, RE-5299, Shanghai, China) to obtain the extract. The resulting oils were kept in vials $(50 \mathrm{~mL})$ and placed in a refrigerator until further use.

The extracted oils were analyzed by gas chromatography-mass spectrometry (GC-MS) equipment (7890B/5977A, Agilent, Santa Clara, California, USA). A capillary column (HP-5MS, $30 \mathrm{~m}, 0.25 \mathrm{~mm}$ ID, df $1 / 40.25 \mathrm{~mm}$ ) was used for the separation system (Ren et al., 2019). Oven temperature was set at $40{ }^{\circ} \mathrm{C}(3 \mathrm{~min})$ and reached $250{ }^{\circ} \mathrm{C}\left(5^{\circ} \mathrm{C} \mathrm{min}^{-1}\right)$, and the carrier gas was highly pure helium (99.999\%) with a $1 \mathrm{~mL} \mathrm{~min}^{-1}$ flow rate. The GC-MS analysis was performed with the MS system (5977A MSD, Agilent). The ion source temperature was $270{ }^{\circ} \mathrm{C}$ and the transmission line temperature was $300{ }^{\circ} \mathrm{C}$. The ionization energy was $70 \mathrm{eV}$ and a mass range from 50 to $550 \mathrm{amu}$. Compounds were identified by comparing their mass spectrum with the mass spectrum of known components from the National Institute of Standards and Technology (NIST) library (NIST, Gaithersburg, Maryland, USA).

\section{Treatment preparations}

Treatment preparations started as a pre-step for biological assays. The first step aimed to prepare the concentrations, and the oils were filtered with a syringe filter ( $13 \mathrm{~mm}$ diameter $0.45 \mu$ filter) to improve quality. Afterward, $500 \mathrm{mg}$ of each type of oil was diluted with $10 \mathrm{~mL}$ acetone to obtain the highest concentration $\left(50 \mathrm{mg} \mathrm{mL}^{-1}\right)$ for the present study. Other 
concentrations $\left(25.0,12.5\right.$, and $\left.6.25 \mathrm{~m} \mathrm{~mL}^{-1}\right)$ were prepared by serial dilutions. To calculate the dose per area $\left(\mathrm{mg} \mathrm{cm}^{-2}\right)$, the concentration $\left(\mathrm{mg} \mathrm{mL}^{-1}\right)$ in $1 \mathrm{~mL}$ (applied on a Petri dish) was divided with the area of the Petri dish $\left(44.20 \mathrm{~cm}^{2}\right)$. Accordingly, the calculated doses were $1.131,0.566,0.283$, and $0.142 \mathrm{mg} \mathrm{cm}^{-2}$.

\section{Toxicity assay}

The residual film method was selected to determine the contact toxicity of B. aegyptiaca oils against T. castaneum (Sabiha et al., 2017). Accordingly, $1 \mathrm{~mL}$ of each concentration was applied in Petri dishes $(7.5 \mathrm{~cm})$ and the solvent (acetone) was left to evaporate for $30 \mathrm{~min}, 10 \mathrm{~T}$. castaneum adults were released in each Petri dish, dishes were placed in the incubator, and each treatment was replicated four times, including the control with only acetone (Paramasivam and Selvi, 2017). Insect mortality was recorded after 12, 24, 36, and $48 \mathrm{~h}$. The experiment used a completely randomized design. Data were analyzed by one-way ANOVA and the level of significant differences was $\mathrm{P}<0.05$. Duncan's multiple range test was used. Probit analysis (Finney, 1971) was used to determine median lethal dose $\left(\mathrm{LD}_{50}\right)$ values with SPSS version 16.0 (IBM, Armonk, New York, USA).

\section{RESULTS AND DISCUSSION}

\section{Toxicity assay}

The chloroform extract of B. aegyptiaca seeds caused $100 \%$ mortality of $T$. castaneum at $1.131 \mathrm{mg} \mathrm{cm}^{-2}$ after $12 \mathrm{~h}$ of exposure; there were nonsignificant differences $(\mathrm{p}=0.611)$ with hexane, which obtained $97.5 \%$ at the same dose and reached $100 \%$ mortality after $24 \mathrm{~h}$. In this $24-\mathrm{h}$ interval the second dose $\left(0.566 \mathrm{mg} \mathrm{cm}^{-2}\right)$ exhibited $90 \%$ mortality for the chloroform extract and $87.5 \%$ for hexane, with no differences $(\mathrm{p}=0.510)$ between them. After $36 \mathrm{~h}$, the chloroform extract recorded $100 \%$ mortality and hexane extract $97.5 \%$; hexane achieved $100 \%$ mortality after $48 \mathrm{~h}$ (Table 1). Our result for the hexane extract, was similar to findings by Nwaogu et al. (2013), who observed $100 \%$ mortality of cowpea weevil (Callosobruchus maculatus [Fabr.]) after $48 \mathrm{~h}$ on cowpea treated with $0.5 \mathrm{~mL}$ hexane extract of B. aegyptiaca seeds. In addition, various studies have demonstrated the insecticidal activities of chloroform extract against pests from other plants such as shrubby whilevein, Sanchezia speciosa Hook. F. (Rafshanjani et al., 2014; Mondal et al., 2014). The ethanol extract showed the lowest mortality at all doses compared with those extracts, and the highest dose $\left(1.131 \mathrm{mg} \mathrm{cm}^{-2}\right)$ obtained $40 \%$ mortality at the end of the experiment $(48 \mathrm{~h}$ ) (Table 1$)$. This result could imply that bioactive ingredients extracted with this solvent were low compared with other solvents.

In general, the chloroform extract caused $100 \%$ mortality at 1.131 and $0.566 \mathrm{mg} \mathrm{cm}^{-2}$ after 12 and $36 \mathrm{~h}$ of exposure, respectively, and the hexane extract after 24 and $48 \mathrm{~h}$ at the same doses, respectively (Table 1).

Table 1. Mortality of red flour beetle (Tribolium castaneum) adults exposed to oil doses (hexane, chloroform, and ethanol extracts) of desert date (Balanites aegyptiaca) seeds in a contact toxicity bioassay after 12, 24, 36, and $48 \mathrm{~h}$.

\begin{tabular}{|c|c|c|c|c|c|}
\hline \multirow[b]{2}{*}{ Treatment } & \multirow[b]{2}{*}{ Dose } & \multicolumn{4}{|c|}{ Mortality \pm SE } \\
\hline & & $12 \mathrm{~h}$ & $24 \mathrm{~h}$ & $36 \mathrm{~h}$ & $48 \mathrm{~h}$ \\
\hline & $\mathrm{mg} \mathrm{cm}{ }^{-2}$ & & $\%$ & & \\
\hline \multirow[t]{4}{*}{ Balanites aegyptiaca chloroform } & 1.131 & $100.0 \pm 0.25 \mathrm{a}$ & $100.0 \pm 0.00 \mathrm{a}$ & $100.0 \pm 0.00 \mathrm{a}$ & $100.0 \pm 0.00 \mathrm{a}$ \\
\hline & 0.566 & $77.5 \pm 0.25 b$ & $90.0 \pm 0.00 \mathrm{~b}$ & $100.0 \pm 0.00 \mathrm{a}$ & $100.0 \pm 0.00 \mathrm{a}$ \\
\hline & 0.283 & $37.5 \pm 0.48 \mathrm{~d}$ & $45.0 \pm 0.29 c$ & $52.5 \pm 0.48 b$ & $57.5 \pm 0.25 b$ \\
\hline & 0.142 & $5.0 \pm 0.50 \mathrm{fg}$ & $12.5 \pm 0.48 \mathrm{de}$ & $12.5 \pm 0.48 \mathrm{~d}$ & $15.0 \pm 0.29 \mathrm{de}$ \\
\hline \multirow[t]{4}{*}{ B. aegyptiaca hexane } & 1.131 & $97.5 \pm 0.25 \mathrm{a}$ & $100.0 \pm 0.00 \mathrm{a}$ & $100.0 \pm 0.00 \mathrm{a}$ & $100.0 \pm 0.00 \mathrm{a}$ \\
\hline & 0.566 & $65.0 \pm 0.50 \mathrm{c}$ & $87.5 \pm 0.25 b$ & $97.5 \pm 0.25 \mathrm{a}$ & $100.0 \pm 0.00 \mathrm{a}$ \\
\hline & 0.283 & $27.5 \pm 0.48 \mathrm{e}$ & $37.5 \pm 0.48 \mathrm{c}$ & $50.0 \pm 0.41 b$ & $52.5 \pm 0.25 b$ \\
\hline & 0.142 & $5.0 \pm 0.29 \mathrm{ef}$ & $7.5 \pm 0.25 \mathrm{ef}$ & $7.5 \pm 0.25 \mathrm{de}$ & $12.5 \pm 0.48 \mathrm{de}$ \\
\hline \multirow[t]{4}{*}{ B. aegyptiaca ethanol } & 1.131 & $12.5 \pm 0.48 \mathrm{f}$ & $20.0 \pm 0.00 \mathrm{~d}$ & $32.5 \pm 0.25 c$ & $40.0 \pm 0.41 \mathrm{c}$ \\
\hline & 0.566 & $5.0 \pm 0.29 \mathrm{fg}$ & $10.0 \pm 0.41 \mathrm{e}$ & $12.5 \pm 0.48 d$ & $20.0 \pm 0.41 \mathrm{~d}$ \\
\hline & 0.283 & $2.5 \pm 0.25 \mathrm{fg}$ & $5.0 \pm 0.29 \mathrm{ef}$ & $5.0 \pm 0.29 \mathrm{de}$ & $7.5 \pm 0.25 \mathrm{ef}$ \\
\hline & 0.142 & $0.0 \pm 0.00 \mathrm{~g}$ & $0.0 \pm 0.00 \mathrm{f}$ & $0.0 \pm 0.00 \mathrm{e}$ & $0.0 \pm 0.00 \mathrm{f}$ \\
\hline Control & 0.00 & $0.0 \pm 0.00 \mathrm{~g}$ & $0.0 \pm 0.00 \mathrm{f}$ & $0.0 \pm 0.00 \mathrm{e}$ & $0.0 \pm 0.00 \mathrm{f}$ \\
\hline
\end{tabular}

Values represent the mean of four replicates each consisting of 10 insects. Means followed by the same letters are not significantly different from each other at $\mathrm{P}<0.05$. 
The $\mathrm{LD}_{50}$ of the chloroform extract were $0.347,0.285,0.250$, and $0.239 \mathrm{mg} \mathrm{cm}^{-2}$ after $12,24,36$, and $48 \mathrm{~h}$ of exposure, respectively, $0.411,0.327,0.271$, and $0.251 \mathrm{mg} \mathrm{cm}^{-2}$ after $12,24,36$, and $48 \mathrm{~h}$, respectively, for the hexane extract, and $5.564,3.392,1.784$, and $\mathrm{mg} \mathrm{cm}^{-2}$ after 12, 24, 36, and $48 \mathrm{~h}$, respectively, for the ethanol extract (Table 2). We observed that the $\mathrm{LD}_{50}$ of chloroform after 12,24 , and $36 \mathrm{~h}$ was similar to the $\mathrm{LD}_{50}$ of the hexane extract after 24,36 , and $48 \mathrm{~h}$, respectively. The $\mathrm{LD}_{50}$ values of the chloroform extract detected in the present study concur with Khan et al. (2014), who reported that the $\mathrm{LD}_{50}$ of the chloroform fraction of the rhizome of the oakleaf fern (Drynaria quercifolia [L.] J. Sm.) against $T$. castaneum was 0.400 and $0.370 \mathrm{mg} \mathrm{cm}^{-2}$ after 24 and $48 \mathrm{~h}$, respectively. The small differences are related to which part of the plant was evaluated, which means that B. aegyptiaca seeds could be more toxic for pests than the rhizome of D. quercifolia.

It is suggested that contact toxicity could be attributable to the high quantity and/or good quality of active compounds in B. aegyptiaca seeds. According to Kumar et al. (2019), the seeds of this plant contain alkaloids, saponins, steroids, flavonoids, tannins, and phenolic compounds, which have different biological actions such as insecticidal activity. Similarly, the GC-MS analysis detected (9Z,12Z)-octadeca-9,12-dienoic acid, hexadecanoic acid, (Z)-octadec-9-enoic acid, 3,3-dihydroxypropyl hexadecanoate, ethyl hexadecanoate, and methyl hexadecanoate in the plant, which have good insecticidal activity (Hema et al., 2011; Ramos-López et al., 2012; Koul, 2016). Furthermore, Elamin and Satti (2013) demonstrated the insecticidal potential of B. aegyptiaca seeds against stored product pest Khapra beetle (Trogoderma granarium Everts).

\section{Phytochemical analysis}

The major components of B. aegyptiaca seed oils (chloroform, hexane, and ethanol extracts) identified in the present study were $(9 Z, 12 Z)$-octadeca-9,12-dienoic acid $(63.08 \%, 63.66 \%$, and $64.52 \%)$, hexadecanoic acid $(15.88 \%$, $15.86 \%$, and $10.63 \%),(Z)$-octadec-9-enoic acid $(11.35 \%, 9.01 \%$, and $9.11 \%)$, and (E)-octadec-6-enoic acid (4.86\%, $3.95 \%$, and $7.65 \%$ ), respectively (Tables 3, 4, and 5). More main components were found in certain extracts, such as 2,3-dihydroxypropyl $(E)$-octadec-9-enoate (1.30\%) in the chloroform extract (Table 3) and 1,3-dihydroxypropan-2-yl (Z)octadec-9-enoate (6.66\%) and 1-3-hydroxypropan-2-yl (9Z,12Z)-octadeca-9,12-dienoate (2.65\%) in the ethanol extract (Table 5). The results were consistent with findings by Bai et al. (2014), who indicated that the GC-MS analysis for the chloroform extract of babul (Acacia nilotica [L.] Delile) leaves detected various compounds, including (9Z,12Z)octadeca-9,12-dienoic acid, hexadecanoic acid, and ethyl hexadecanoate. These findings concur with those mentioned by Kalpana et al. (2012), who detected (9Z,12Z)-octadeca-9,12-dienoic acid, hexadecanoic acid, and (Z)-octadec-9-enoic acid in the ethanol extract of ladynut (Entada pursaetha DC.) seeds. Warra and Abubakar (2015) reported that the hexane extract of jatropha (Jatropha curcas L.) seeds contained fatty acids such as (Z)-octadec-9-enoic acid, octadecanoic acid, and $(E)$-octadec-6-enoic acid.

Table 2. Median lethal dose $\left(\mathrm{LD}_{50}\right)$ values of desert date (Balanites aegyptiaca) seed oils (hexane, chloroform, and ethanol extracts) against red flour beetle (Tribolium castaneum) adults in a contact toxicity bioassay after 12, 24, 36, and $48 \mathrm{~h}$.

\begin{tabular}{|c|c|c|c|c|c|}
\hline \multirow[b]{2}{*}{ Extract } & \multirow{2}{*}{$\begin{array}{c}\text { Exposure } \\
\text { time }\end{array}$} & \multirow[b]{2}{*}{$\mathrm{LD}_{50}$} & \multicolumn{2}{|c|}{ 95\% Confidence intervals } & \multirow[b]{2}{*}{ Chi-square; $\chi^{2}(\mathrm{df})$} \\
\hline & & & Lower limit & Upper limit & \\
\hline & $\mathrm{h}$ & $\mathrm{mg} \mathrm{cm} \mathrm{cm}^{-2}$ & & & \\
\hline \multirow[t]{4}{*}{ Chloroform } & 12 & 0.347 & 0.30 & 0.41 & 1.999 (2) \\
\hline & 24 & 0.285 & 0.25 & 0.33 & $0.807(2)$ \\
\hline & 36 & 0.251 & 0.22 & 0.29 & $2.973(2)$ \\
\hline & 48 & 0.239 & 0.21 & 0.27 & $2.407(2)$ \\
\hline \multirow[t]{4}{*}{ Hexane } & 12 & 0.411 & 0.35 & 0.48 & 1.047 (2) \\
\hline & 24 & 0.327 & 0.28 & 0.38 & $1.593(2)$ \\
\hline & 36 & 0.271 & 0.24 & 0.30 & $0.638(2)$ \\
\hline & 48 & 0.251 & 0.22 & 0.29 & $2.973(2)$ \\
\hline \multirow[t]{4}{*}{ Ethanol } & 12 & 5.564 & 2.01 & 99292.87 & $0.348(2)$ \\
\hline & 24 & 3.392 & 1.64 & 73.31 & $0.736(2)$ \\
\hline & 36 & 1.784 & 1.197 & 4.837 & $0.517(2)$ \\
\hline & 48 & 1.398 & 1.005 & 2.769 & $0.803(2)$ \\
\hline
\end{tabular}

df: Degrees of freedom. 
Table 3. List of compounds detected in the chloroform extract of Balanites aegyptiaca seeds.

\begin{tabular}{|c|c|c|c|c|}
\hline $\mathrm{Nr}$ & Compound & $\begin{array}{l}\text { Molecular } \\
\text { formula }\end{array}$ & $\begin{array}{l}\text { Retention } \\
\text { time }\end{array}$ & $\begin{array}{l}\text { Peak } \\
\text { area }\end{array}$ \\
\hline & & & Min & $\%$ \\
\hline 1 & Pyridine & $\mathrm{C}_{5} \mathrm{H}_{5} \mathrm{~N}$ & 4.87 & 0.03 \\
\hline 2 & Furan-3-carbaldehyde & $\mathrm{C}_{5} \mathrm{H}_{4} \mathrm{O}_{2}$ & 6.36 & 0.03 \\
\hline 3 & 2-Fluoro-2-methylpropane & $\mathrm{C}_{4} \mathrm{H}_{9} \mathrm{~F}$ & 15.94 & 0.22 \\
\hline 4 & Trimethyl-(2-propan-2ylidenecyclopropyl)silane & $\mathrm{C}_{9} \mathrm{H}_{18} \mathrm{Si}$ & 30.97 & 0.07 \\
\hline 5 & 1-Methylcyclohexane-1,2,3,4,5,6-hexol & $\mathrm{C}_{7} \mathrm{H}_{14} \mathrm{O}_{6}$ & 38.90 & 0.03 \\
\hline 6 & Methyl hexadecanoate & $\mathrm{C}_{17} \mathrm{H}_{34} \mathrm{O}_{2}$ & 41.41 & 0.31 \\
\hline 7 & Ethyl hexadecanoate & $\mathrm{C}_{18} \mathrm{H}_{36} \mathrm{O}_{2}$ & 43.09 & 0.31 \\
\hline 8 & Hexadecanoic acid & $\mathrm{C}_{16} \mathrm{H}_{32} \mathrm{O}_{2}$ & 43.45 & 15.88 \\
\hline 9 & $(9 Z, 12 Z)$-Octadeca-9,12-dienoic acid & $\mathrm{C}_{18} \mathrm{H}_{32} \mathrm{O}_{2}$ & 47.36 & 63.08 \\
\hline 10 & (E)-Octadec-6-enoic acid & $\mathrm{C}_{18} \mathrm{H}_{34} \mathrm{O}_{2}$ & 47.84 & 4.86 \\
\hline 11 & 1-3-Hydroxypropan-2-yl-(9Z,12Z)-octadeca-9,12-dienoate & $\mathrm{C}_{21} \mathrm{H}_{38} \mathrm{O}_{4}$ & 50.48 & 0.88 \\
\hline 12 & 2,3-Dihydroxypropyl $(E)$-octadec-9-enoate & $\mathrm{C}_{21} \mathrm{H}_{40} \mathrm{O}_{4}$ & 50.62 & 1.30 \\
\hline 13 & (Z)-Octadec-9-enoic acid & $\mathrm{C}_{18} \mathrm{H}_{34} \mathrm{O}_{2}$ & 50.75 & 11.35 \\
\hline 14 & 3,3-Dihydroxypropyl hexadecanoate & $\mathrm{C}_{19} \mathrm{H}_{38} \mathrm{O}_{4}$ & 54.16 & 0.52 \\
\hline
\end{tabular}

Table 4. List of compounds detected in hexane extract of Balanites aegyptiaca seeds.

\begin{tabular}{llccc}
\hline $\mathrm{Nr}$ & \multicolumn{1}{c}{ Compound } & $\begin{array}{c}\text { Molecular } \\
\text { formula }\end{array}$ & $\begin{array}{c}\text { Retention } \\
\text { time }\end{array}$ & $\begin{array}{c}\text { Peak } \\
\text { area }\end{array}$ \\
\hline & & & Min & $\%$ \\
1 & Benzene & $\mathrm{C}_{6} \mathrm{H}_{6}$ & 2.58 & 0.02 \\
2 & Methyl hexadecanoate & $\mathrm{C}_{17} \mathrm{H}_{34} \mathrm{O}_{2}$ & 41.40 & 0.02 \\
3 & Hexadecanoic acid & $\mathrm{C}_{16} \mathrm{H}_{32} \mathrm{O}_{2}$ & 43.90 & 15.86 \\
4 & (9Z,12Z)-Octadeca-9,12-dienoic acid & $\mathrm{C}_{18} \mathrm{H}_{32} \mathrm{O}_{2}$ & 47.17 & 63.66 \\
5 & (E)-Octadec-6-enoic acid & $\mathrm{C}_{18} \mathrm{H}_{34} \mathrm{O}_{2}$ & 47.73 & 9.01 \\
6 & Octadecanoic acid & $\mathrm{C}_{18} \mathrm{H}_{36} \mathrm{O}_{2}$ & 49.93 & 0.83 \\
7 & (Z)-Octadec-9-enoic acid & $\mathrm{C}_{18} \mathrm{H}_{34} \mathrm{O}_{2}$ & 51.52 & 3.95 \\
8 & 1-3-Hydroxypropan-2-yl (9Z,12Z)-octadeca-9,12-dienoate & $\mathrm{C}_{21} \mathrm{H}_{38} \mathrm{O}_{4}$ & 52.41 & 0.05 \\
\hline
\end{tabular}

Table 5. List of compounds detected in ethanol extract of Balanites aegyptiaca seeds.

\begin{tabular}{llccc}
\hline $\mathrm{Nr}$ & \multicolumn{1}{c}{ Compound } & $\begin{array}{c}\text { Molecular } \\
\text { formula }\end{array}$ & $\begin{array}{c}\text { Retention } \\
\text { time }\end{array}$ & $\begin{array}{c}\text { Peak } \\
\text { area }\end{array}$ \\
\hline & & & Min & $\%$ \\
1 & Hexadecanoic acid & $\mathrm{C}_{16} \mathrm{H}_{32} \mathrm{O}_{2}$ & 43.82 & 10.63 \\
2 & (9Z,12Z)-Octadeca-9,12-dienoic acid & $\mathrm{C}_{18} \mathrm{H}_{36} \mathrm{O}_{2}$ & 45.25 & 64.52 \\
3 & Octadecanoic acid & $\mathrm{C}_{18} \mathrm{H}_{36} \mathrm{O}_{2}$ & 45.77 & 0.26 \\
4 & (Z)-Octadec-9-enoic acid & $\mathrm{C}_{18} \mathrm{H}_{34} \mathrm{O}_{2}$ & 47.55 & 9.11 \\
5 & (E)-Octadec-6-enoic acid & $\mathrm{C}_{18} \mathrm{H}_{34} \mathrm{O}_{2}$ & 47.62 & 7.65 \\
6 & 1-3-Hydroxypropan-2-yl (9Z,12Z)-octadeca-9,12-dienoate & $\mathrm{C}_{21} \mathrm{H}_{38} \mathrm{O}_{4}$ & 50.47 & 2.65 \\
7 & 1,3-dihydroxypropan-2-yl (Z)-octadec-9-enoate & $\mathrm{C}_{21} \mathrm{H}_{40} \mathrm{O}_{4}$ & 50.73 & 6.66 \\
8 & 3,3-Dihydroxypropyl hexadecanoate & $\mathrm{C}_{19} \mathrm{H}_{38} \mathrm{O}_{4}$ & 54.12 & 0.28 \\
\hline
\end{tabular}

\section{CONCLUSIONS}

Balanites aegyptiaca seed oils exhibit strong insecticidal activity against Tribolium castaneum adults through contact toxicity. The main chemical compounds of the oils are $(9 Z, 12 Z)$-octadeca-9,12-dienoic acid, hexadecanoic acid, (Z)octadec-9-enoic acid, and (E)-octadec-6-enoic acid. These findings suggest that B. aegyptiaca oils could be useful as a botanical insecticide against the pest. Moreover, our study can be considered as an approach to future studies about this plant to produce a commercial insecticide.

\section{ACKNOWLEDGEMENTS}

This study was sponsored by the National Natural Science Foundation of China-Shanxi Joint Funds (Grant Nr U1610222), Applied Basic Research Programs of Shanxi Province, China (Grant Nr 201801D121269). 


\section{REFERENCES}

Agrafioti, P., Athanassiou, C.G., and Nayak, M.K. 2019. Detection of phosphine resistance in major storedproduct insects in Greece and evaluation of a field resistance test kit. Journal of Stored Products Research 82:40-47. doi:10.1016/j.jspr.2019.02.004.

Al-Thobaiti, S.A., and Abu Zeid, I.M. 2018. Medicinal properties of desert date plants (Balanites aegyptiaca) -an overview. Global Journal of Pharmacology 12:01-12. doi:10.5829/idosi.gjp.2018.01.12.

Bai, S., Seasotiya, L., Malik, A., Bharti, P., and Dalal, S. 2014. GC-MS analysis of chloroform extract of Acacia nilotica L. leaves. Journal of Pharmacognosy and Phytochemistry 2:79-82.

Chiffelle, I., Huerta, A., Bobadilla, V., Macuada, G., Araya, J.E., Curkovic, T., et al. 2019. Antifeedant and insecticidal effects of extracts from Melia azedarach fruits and Peumus boldus leaves on Xanthogaleruca luteola larvae. Chilean Journal of Agricultural Research 79:609-615. doi:10.4067/S0718-58392019000400609.

Chothani, D.L., and Vaghasiya, H.U. 2011. A review on Balanites aegyptiaca Del (desert date): phytochemical constituents, traditional uses, and pharmacological activity. Pharmacognosy Reviews 5:55-62. doi:10.4103/0973-7847.79100.

Damalas, C.A., and Koutroubas, S.D. 2016. Farmers' exposure to pesticides: toxicity types and ways prevention. Toxics 4:1-10. doi:10.3390/toxics4010001.

Dhaniya, M.V., and Dayanandan, S. 2016. Common medicinal plants as repellents against stored grain insects Sitophilus oryzae and Tribolium castaneum. Journal of Agriculture and Veterinary Science 9:71-77. doi:10.9790/2380-0908027177.

Djeghader, N., Aissaoui, L., Amira, K., and Boudjelida, H. 2018. Toxicity evaluation and effects on the development of a plant extract, the saponin, on the domestic mosquito, Culex pipiens. International Journal of Mosquito Research 5:01-05.

Elamin, M.M., and Satti, A.A. 2013. Insecticidal potentialities of Balanites aegyptiaca extracts against the khapra beetle (Trogoderma granarium). Global Advanced Research Journal of Environmental Science and Toxicology 2:5-10.

Finney, D.J. 1971. Probit analysis. $3^{\text {rd }}$ ed. Cambridge University Press, London, England.

Gupta, D., Dubey, J., and Kumar, M. 2016. Phytochemical analysis and antimicrobial activity of some medicinal plants against selected common human pathogenic microorganisms. Asian Pacific Journal of Tropical Disease 6:15-20. doi:10.1016/S2222-1808(15)60978-1.

Hema, R., Kumaravel, S., and Alagusundaram, K. 2011. GC/MS determination of bioactive components of Murraya koenigii. Journal of American Science 7:80-83.

Hu, J., Wang, W., Dai, J., and Zhu, L. 2019. Chemical composition and biological activity against Tribolium castaneum (Coleoptera: Tenebrionidae) of Artemisia brachyloba essential oil. Industrial Crops and Products 128:29-37. doi:10.1016/j.indcrop.2018.10.076.

Jatau, A., Majeed, Q., Yahaya, M.A., and Sokoto, M.B. 2018. Potential of five local plant as protectant against hide beetle, Dermestes maculatus Degeer infesting dry cat fish; Clarias gariepinus Burchell. Asian Journal of Research in Zoology $1: 1-8$.

Johnson, J. 2013. Pest control in postharvest nuts. p. 56-87. In Harris, L.J. (ed.) Improving the safety and quality of nuts. Woodhead Publishing Limited, Cambridge, UK.

Kalpana, D.V., Shanmugasundaram, R., and Mohan, V.R. 2012. GC-MS analysis of ethanol extract of Entada pursaetha DC seed. Bioscience Discovery 3:30-33.

Khan, A., Islam, M.H., Islam, M.E., Al-Bari, M.A., Parvin, M.S., Sayeed, M.A., et al. 2014. Pesticidal and pest repellency activities of rhizomes of Drynaria quercifolia (J. Smith) against Tribolium castaneum (Herbst). Biological Research 47:51. doi:10.1186/0717-6287-47-51.

Koul, O. 2016. The handbook of naturally occurring insecticidal toxins. CAB International, Wallingford, UK.

Kumar, S., Kumar, A., Mishra, A., Singh, N., and Dwivedi, K.N. 2019. Pharmacognostical studies, phytochemical Screening and thin layer chromatography (TLC) profile of seed, seed coat and leaves of Ingudi (Balanites aegyptiaca (Linn.) Delile) with special reference to wound healing. International Journal of Research and Analytical Reviews 6:434-442.

Lazzari, S.M.N., and Lazzari, F.A. 2012. Insect pests in stored grain. p. 417-450. In Panizzi, A.R., and Parra, J.R.P. (eds.) Insect bioecology and nutrition for integrated pest management. Taylor \& Francis Group, Boca Raton, Florida, USA.

Maksymiv, I. 2015. Pesticides: benefits and hazards. Journal of Vasyl Stefanyk Precarpathian National University 2:70-76. doi:10.15330/jpnu.2.1.70-76.

Manji, A.J., Sarah,E.E., and Modibbo, U.U. 2013. Studies on the potentials of Balanites aegyptiaca seed oil as raw material for the production of liquid cleansing agents. International Journal of Physical Sciences 8:1655-1660.

Mendoza-García, E.E., Ortega-Arenas, L.D., Serrato-Cruz, M.A., Villanueva-Jiménez, J.A., López-Arroyo, J.I., and PérezPacheco, R. 2019. Chemical composition, toxicity, and repellence of plant essential oils against Diaphorina citri (Hemiptera: Liviidae). Chilean Journal of Agricultural Research 79:636-647. doi:10.4067/S0718-58392019000400636.

Mishra, B.B., Tripathi, S.P., and Tripathi, C.P.M. 2016. Effect of temperature at fixed relative humidity in fecundity and development of Tribolium castaneum (Herbst). Journal of Entomology and Zoology Studies 4:255-257. 
Mondal, O., Haque, E., Haque, J., and Khan, A. 2014. Insecticidal activities of Abroma augusta (L.) chloroform and methanol extracts against Tribolium castaneum (Herbst) adults. Journal of Life and Earth Science 8:11-15. doi:10.3329/jles.v8i0.20134.

Nwaogu, J., Yahaya, M.A., and Bandiya, H.M. 2013. Insecticidal efficacy of oil extracts of Balanites aegyptiaca seeds and cashew nuts against Callosobruchus maculatus Fabr. (Coleoptera: Bruchidae). African Journal of Agricultural Research 8:3285-3288. doi:10.5897/AJAR12.1978.

Rafshanjani, M.A., Parvin, S., Abdul Kader, M.D., Saha, M.R., and Akhtar, M.A. 2014. In vitro antibacterial, antifungal and insecticidal activities of ethanolic extract and its fractionates of Sanchezia speciose Hook. F. International Research Journal of Pharmacy 5(9):717-720. doi:10.7897/2230-8407.0509146.

Rahim, S., and Iqbal, M. 2019. Exploring enhanced insecticidal activity of mycelial extract of Trichoderma harzianum against Diuraphis noxia and Tribolium castaneum. Sarhad Journal of Agriculture 35(3):757-762. doi:10.17582/journal.sja/2019/35.3.757.762.

Ramos-López, M.A., González-Chávez, M.M., Cárdenas-Ortega, N.C., Zavala Sánchez, M.A., and Pérez G.S. 2012. Activity of the main fatty acid components of the hexane leaf extract of Ricinus communis against Spodoptera frugiperda. African Journal of Biotechnology 11:4274-4278. doi:10.5897/AJB11.3727.

Ren, J., Li, J., Li, J., Chen, Z., and Cheng, F. 2019. Tracking multiple aromatic compounds in a full-scale coking wastewater reclamation plant: Interaction with biological and advanced treatments. Chemosphere 222:431-439. doi:10.1016/j.chemosphere.2019.01.179.

Rozman, V. 2015. Control of stored products pests by natural products. Integrated Protection of Stored Products IOBC-WPRS Bulletin 111:295-299.

Paramasivam, M., and Selvi, C. 2017. Laboratory bioassay methods to assess the insecticide toxicity against insect pests-A review. Journal of Entomology and Zoology Studies 5:1441-1445.

Sabiha, S., Ali, H., Hasan, K., Rahman, A.S.M.S., and Islam, N. 2017. Bioactive potentials of Melia azedarach L. with special reference to insecticidal, larvicidal and insect repellent activities. Journal of Entomology and Zoology Studies 5:1799-1802.

Satpute, S.B., and Vanmare, D.J. 2018. Phytochemical analysis of leaf extract of Balanites aegyptica L. by HRLC-MS analysis . Journal of Pharmacognosy and Phytochemistry 7:1736-1739.

Satti, A.A., and Elamin, M.M. 2012. Insecticidal activities of two meliaceous plants against Trogoderma granarium Everts (Coleoptera: Dermestidae). International Journal of Science and Nature 3:696-701.

Trivedi, A, Nayak, N., and Kumar, J. 2018. Recent advances and review on use of botanicals from medicinal and aromatic plants in stored grain pest management. Journal of Entomology and Zoology Studies 6:295-300.

Warra, A.A., and Abubakar, A. 2015. GC-MS analysis of hexane extract of Jatropha curcas L. seed oil. World Journal of Biomedicine and Pharmaceutical Sciences 1:15-21.

Wijayaratne, L.K.W., Arthur, F.H., and Whyard, S. 2018. Methoprene and control of stored-product insects. Journal of Stored Products Research 76:161-169. doi:10.1016/j.jspr.2016.09.001.

Yaseen, M., Kausar, T., Praween, B., Shah, S.J., Jan, Y., Shekhawat, S.S., et al. 2019. Insect pest infestation during storage of cereal grains, pulses and oilseeds. p. 209-234. In Malik, A., Erginkaya, Z., and Erten, H. (eds.) Health and safety aspects of food processing technologies. Springer, Cham, Switzerland. 